Reimar Walthert

\title{
The First Twenty Years of Saxhorn Tutors
}

Subsequent to Adophe Sax's relocation to Paris in I842 and his two saxhorn/saxotromba patents of I843 and I845, numerous saxhorn tutors were published by different authors. After the contest on the Champ-de-Mars on 22 April I845 and the decree by the Ministre de la guerre in August I845 that established the use of saxhorns in French military bands, there was an immediate need for tutors for this new instrument. The Bibliothèque nationale de France owns around 35 tutors published between I 845 and I 865 for this family of instruments. The present article offers a short overview of these early saxhorn tutors and will analyse both their contents and their underlying pedagogical concepts.

Early saxhorn tutors in the Bibliothèque nationale de France The whole catalogue of the French national library can now be found online at the library's website bnf.fr. It has two separate indices that are of relevance for research into saxhorn tutors. Those intended specifically for the saxhorn can be found under the index number "Vm8-o", whereas cornet tutors are listed under "Vm8-1". But the second index should not be ignored with regard to saxhorn tutors, because tutors intended for either cornet or saxhorn are listed only here. The most famous publication in this category is Jean-Baptiste Arban's Grande méthode complète de cornet à pistons et de saxhorn. Meanwhile many of these tutors have been digitised and made accessible on the website gallica.fr.

Publication periods It is difficult to date the saxhorn tutors in question. On one hand there is the stamp of the Bibliothèque nationale de France, which cannot always be relied upon. On the other hand, it is possible to date some publications by means of the plate number engraved by the editor. However, this is only possible if the editor kept clear records of his publications and if those records are still accessible today, which is not always the case. ${ }^{\mathrm{I}}$

Below is a chronological list of all saxhorn tutors that appeared between I845 and I865. Where not indicated otherwise, our dating follows the stamp of the Bibliothèque nationale de France. ${ }^{2}$ Dates in parenthesis are dates as suggested by the plate number.

1 For dating with plate numbers, the standard reference work is Anik Devriès/François Lesure: Dictionnaire des éditeurs de musique française, 3 vols., Geneva I979-1988. The volume relevant for this essay is volume 2, featuring the years 1820 to I9I4.

2 A list of saxhorn tutors published between I845 and I900 can be found in Eugenia Mitroulia: Adolphe Sax's brasswind production with a focus on saxhorns and related instruments, Edinburgh 20II, Appendix F; www.era.lib.ed.ac.uk/handle/r842/5490 (22 June 20I8). 


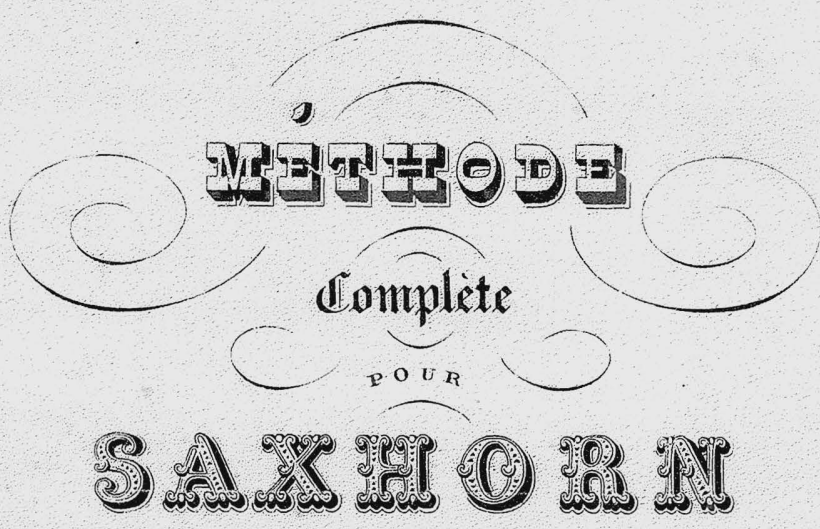

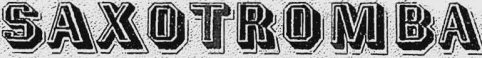

Sopramo, Alto Tenox, Tisanton, Tisasse et fontrebasse

\section{ADOLPHE SAX}

PARTS chen BRANDUS a C' Edileurs

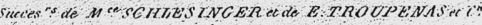

103. Rue Richlieu

FIgURE 1 One of the first saxhorn tutors: Adophe Sax: Méthode Complète pour Saxhorn et Saxotromba, Soprano, Alto, Tenor, Baryton, Basse et Contrebasse à 3, 4 et 5 cylindres suivie d'Exercices pour l'emploi du Compensateur, Paris 1846 


\begin{tabular}{|c|c|c|c|c|c|}
\hline Author & Title & Date & Publisher & Plate No. & Pages \\
\hline $\begin{array}{l}\text { Caussinus, Victor } \\
\text { (I806-I900) }\end{array}$ & $\begin{array}{l}\text { Solfege-Mèthode pour l'enseignement du Cornet à } \\
\text { pistons, de la Trompette-chromatique, Sax-Horns } \\
\text { ou Bugle à pistons, du Sax-tromba ou Trombonne- } \\
\text { alto à pistons }\end{array}$ & I846 a) & $\begin{array}{l}\text { Bureau central de } \\
\text { musique, Paris }\end{array}$ & B. C. I-2 & I00 \\
\hline $\begin{array}{l}\text { Cornette, Victor } \\
\text { (I775-1868) }\end{array}$ & $\begin{array}{l}\text { Méthode complète de sax-horn soprano, contralto, } \\
\text { ténor, baryton basse et contrebasse (ou bombardon) }\end{array}$ & $(\mathrm{I} 846)^{\mathrm{b})}$ & S. Richault, Paris & $7385 . \mathrm{R}$. & 90 \\
\hline $\begin{array}{l}\text { Cornette, Victor } \\
\text { (I775-I868) }\end{array}$ & $\begin{array}{l}\text { Collection de méthodes élémentaires de sax-horn, } \\
\mathrm{N}^{\circ} \text { I, Sax-horn soprano }\end{array}$ & I846 & $\begin{array}{l}\text { Schonenberger, } \\
\text { Paris }\end{array}$ & I28I & 75 \\
\hline $\begin{array}{l}\text { Fessy, Alexandre } \\
(\mathrm{I} 804-1856)\end{array}$ & Méthode complète des saxhorns alto et ténor & I846 & $\begin{array}{l}\text { E. Troupenas \& } \\
\text { Cie, Paris }\end{array}$ & ET I934 & 55 \\
\hline $\begin{array}{l}\text { Forestier, Joseph } \\
\text { (1815-1882) }\end{array}$ & $\begin{array}{l}\text { Méthode complète pour les saxhorns ou bugles }[\ldots] \\
\text { ou sax-tromba ou trombone alto à } 3 \text { cylindres }\end{array}$ & I846 & $\begin{array}{l}\text { Meissonnier et } \\
\text { fils, Paris }\end{array}$ & JM 2366 & II9 \\
\hline Muler, $\mathrm{H}$. & Nouvelle méthode de sax-horn basse & I846 & Joly, Paris & 344 & 33 \\
\hline $\begin{array}{l}\text { Sax, Adolphe } \\
\text { (1814-1894) }\end{array}$ & $\begin{array}{l}\text { Méthode Complète pour Saxhorn et Saxotromba, } \\
\text { Soprano, Alto, Tenor, Baryton, Basse et Contrebasse } \\
\text { à 3, } 4 \text { et } 5 \text { cylindres suivie d'Exercices pour l'emploi } \\
\text { du Compensateur }\end{array}$ & I846 & $\begin{array}{l}\text { Brandus et Cie., } \\
\text { Paris }\end{array}$ & $\begin{array}{l}\text { B. et Cie } \\
4600\end{array}$ & $\mathrm{I} 4 \mathrm{O}$ \\
\hline $\begin{array}{l}\text { Fessy, Alexandre } \\
\text { (I804-I856)/ } \\
\text { Sourdillon }\end{array}$ & $\begin{array}{l}\text { Petite méthode [Méthode de petit saxhorn en } \\
\text { mi b mol] }\end{array}$ & I847 & $\begin{array}{l}\text { Troupenas \& } \\
\text { Cie, Paris }\end{array}$ & ET 2O7I & 47 \\
\hline Dantonet, Édouard & Méthode de basse chromatique & I850 & Michaud, Paris & & $\mathrm{I} 32$ \\
\hline Krenger, Georges & $\begin{array}{l}\text { Nouvelle méthode de clairon soprano en } \\
\text { mi bémol aigu c) }\end{array}$ & $\mathrm{I} 88^{\mathrm{I}}$ & $\begin{array}{l}\text { Alex. Grus aîné } \\
\text { (Paris) }\end{array}$ & & $3^{\mathrm{I}}$ \\
\hline $\begin{array}{l}\text { Schiltz, Jean- } \\
\text { Baptiste }\end{array}$ & $\begin{array}{l}\text { Méthodes de clairons chromatiques ou sax-horns à } \\
\text { pistons ou à cylindres D'après l'Ordonnance du } \\
\text { Ministre de la Guerre et l'avis de l'institut de France }\end{array}$ & 1852 & Aulagnier, Paris & A.A. 1326 & \\
\hline $\begin{array}{l}\text { Carnaud (Jeune), } \\
\text { Félix (I8I5-I890) }\end{array}$ & $\begin{array}{l}\text { Méthode complète et raisonnée pour les sax-horns } \\
\text { contrebasse et baryton à } 3 \text { à } 4 \text { et à } 5 \text { cylindres et pour } \\
\text { le trombone à } 3 \text { pistons }\end{array}$ & 1852 & Lafleur, Paris & & 73 \\
\hline Brulon, Adolphe & Méthode de clairon chromatique & 1853 & Joly, Paris & & \\
\hline Muler, $\mathrm{H}$. & $\begin{array}{l}\text { Méthode de clairon chromatique [Baryton, Basse, } \\
\text { Contrebasse] }\end{array}$ & 1853 & Joly, Paris & $54 \mathrm{I}$ & \\
\hline Saverio & $\begin{array}{l}\text { Méthode complète de cornet à pistons pouvant servir } \\
\text { aux Sax-Horns ou quinton, suivie de } 3 \text { quatuors pour } \\
2 \text { pistons, sax-horn en mi b, ophicleïde ou trombone }\end{array}$ & 1854 & Tournier, Paris & & 69 \\
\hline $\begin{array}{l}\text { Cornette, Victor } \\
\text { (1775-1868) }\end{array}$ & $\begin{array}{l}\text { Petite méthode pour le saxhorn extraite de la grande } \\
\text { méthode }\end{array}$ & I854 & S. Richault, Paris & $\begin{array}{l}\text { 7748. R / } \\
\text { 7749. R }\end{array}$ & \\
\hline Hartmann & $\begin{array}{l}\text { Deux méthodes de sax-horn à pistons ou à cylindres } \\
\text { composées d'après l'ordonnance du ministre de la } \\
\text { guerre et l'avis de l'institut de France }\end{array}$ & $\mathrm{I} 858 \mathrm{~d})$ & $\begin{array}{l}\text { A. Aulagnier, } \\
\text { Paris }\end{array}$ & A.A. 1326 & \\
\hline Dupart, Charles & $\begin{array}{l}\text { Méthode polyphonique ou leçons élémentaires et } \\
\text { progressives pour l'enseignement simultané de } \\
\text { tous les instruments à vent }\end{array}$ & $\begin{array}{l}\text { I859- } \\
\text { I } 868\end{array}$ & Paris & & \\
\hline $\begin{array}{l}\text { Cornette, Victor } \\
\text { (I775-1868) }\end{array}$ & Méthode de basse chromatique à cylindre & I86I & S. Richault, Paris & $4 \mathrm{I} 86 \mathrm{R}$. & 22 \\
\hline Koenik, Hector & Methodes de clairons chromatiques dits sap-horns [sic] & $(\mathrm{I} 86 \mathrm{I}) \mathrm{e}$ & N. Paté, Paris & N. P. 2882 & \\
\hline Brick, A. & $\begin{array}{l}\text { Méthode de Clairon chromatique, Alto mib / } \\
\text { Sax horn ou Saxotromba }\end{array}$ & I862 & Joly, Paris & & 75 \\
\hline
\end{tabular}




\section{Author}

Clodomir, Pierre François (I8I5-I884)

Blancheteau, A.

Carnaud (Jeune),

Félix (I8I5-I890)

Clodomir, Pierre François (I8I5-I884) (†'19I3)

Javelot, Jules (†r890)

Arban, Jean-Baptiste (I825-I889)

Arban, Jean-Baptiste (I825-1889)

Fauconier, BenoîtConstant (18I6-I898)

Willmann, J. J.

Batifort, Octave-

Javelot, Jules (†1890)

Saverio

Girard, Louis

Clodomir, Pierre François (I8I5-I884)
Tilliard, Georges Angel (I84I-I889)
Title

Méthode élémentaire de saxhorn soprano mi b, I862 contralto si b, saxotromba mi b, baryton si b, op. I4

Méthode de Sax-Horhs [sic]

I863

Méthode de sax-horns

Méthode élémentaire de saxhorn-basse à 4 cylindres, op. I9

Méthode d'alto ou saxhorn

Petite méthode de cornet à pistons, bugle ou sax-horn

Grande méthode complète de cornet à pistons et de saxhorn

Extrait de la grande méthode de cornet à pistons et de saxhorn

Méthode pour les instruments de cuivre à cylindres ou à pistons, op. 77

Petite Méthode pour l'étude du cornet et de tout instrument à pistons se jouant avec la clef de sol

Méthode de basse à 3 et 4 cylindres

Petite méthode de cornet à pistons, bugle ou sax-horn

Ecole moderne du Cornet à pistons ou du saxhorn, méthode élémentaire et progressive, nouvelle édition revue, corrigée et augmentée d'une série d'études spéciales par J. Forestier

Petite Méthode de Saxhorn [...]

Méthode élémentaire pour saxhorn (édition populaire)

I863

I86

I864

1865

\section{Date Publisher}

Alphonse Leduc (Paris)

Margueritat, Paris

Carnaud, Paris

I863 Alphonse Leduc (Paris)

$\left.(\mathrm{I} 863)^{\mathrm{f}}\right) \quad$ N. Bousquet, Paris

N. B. I95

I863 A. Huré, Paris

Léon Escudier,

J. B. A. I Paris

Léon Escudier,

Paris

(I864) g) Schott, Paris

S. 362

S. 363

I864 Couturier, Lyon

(I865) h) Alexandre Jaquot, 20I Paris

I865 A. Huré, Paris

C. Prilipp, Paris

P.M.7I

a) According to Devriès/Lesure, Escudier started publishing under the label Bureau central de musique in January I844, so the numbers B. C. 1 and B. C. 2 would suggest an earlier publication. Devriès/Lesure: Dictionnaire, Vol. 2, p. 165

b) Despite the BNF Stamp of I868, Anzenberger dates this tutor to I845, with reference to the Catalogue of Printed Music in the British Library to Ig8o. Friedrich Anzenberger: Ein Überblick über die Trompeten- und Kornettschulen in Frankreich, England, Italien, Deutschland und Österreich von ca. I80o bis ca. I880, Vienna I989, P. 346. The online catalogue of the British Library (www.bl.uk) dates this tutor to circa I845 (26 June 2018). According to Devriès/Lesure, dating publications edited by S. Richault is quite difficult, as this editor simultaneously used different number series for his engraving plates. Sometimes he even reused old numbers or reserved series for composers. The plate number 7385 R. is not listed in the Dictionnaire, but it shows that 7363-7369 R. were published in 1846 and that 7386-7388 R. were published in I847. So a publication date of $\mathrm{I} 846$ or 1847 is very likely. Devriès/Lesure: Dictionnaire, Vol. 2, p. 369 . According to The New Grove Dictionary of Music \& Musicians, Cornette died in February 1868 at the age of 72 (Gérard Streletski: Art. "Cornette, Victor", in: Grove Music Online, www.oxfordmusiconline.com/ grovemusic/view/Io.Io93/gmo/9781561592630.00I.000I/omo-978I561592630-e-0000006520, 22 October 20I8). So 1868 was probably not the year of publication, but the year when the book - perhaps even Cornette's own copy? - was acquired by the Bibliothèque nationale. c) In this method "clairon" stands for "clairon chromatique" (that is, a saxhorn) and not for a natural clairon. This may also be seen in the library index: the shelf mark "Vm8-o" stands for saxhorn tutors.

d) According to the BNF stamp. The name "sax-horn" and the plate number actually suggest an earlier publication. Aulagnier used the number 1388 in 1855 and the numbers $1393-1396$ in 1859 . So this tutor might be ro years older, and belong to the first publication period of saxhorn tutors. Devriès/Lesure: Dictionnaire, Vol. 2, p.38.

e) The BNF stamp dates it to I862, but it was I86ז according to Devriès/Lesure, ibid., p. 338 .

f) The BNF stamp dates it to I850, but according to Devrè/Lesure N. B. 65-I9I were published in I863 and N. B. 208-236 in I864. This seems more likely when we consider the dates of the author and his other publications. Ibid., p. 7 I.

g) Stamp BNF I865, I864 according to Devriès/Lesure, ibid., p. 398.

h) Stamp BNF I863, I865 according to Devirès/Lesure, ibid., p. 240. 
Looking at the publication dates, we can observe that saxhorn tutors were mainly published during three periods:

1845-1847 Right after the contest and the subsequent decree on the future composition of military bands, eight tutors for the new instrument were put on the market. The authors were well-known musicians of the time, such as Victor Cornette, Alexandre Fessy (in collaboration with Arban), Adolphe Sax and Victor Caussinus. Cornette's "Grande" Méthode complète introduces the instrument and gives a clear description of what it is to be used for, and of what instruments could now be replaced by the new instruments of the saxhorn family:

"The family of the Sax-horn will replace the following instruments: the soprano Sax-horn, the Bugle in Eb. The contralto Sax-horn, the Bugle in Bb. The tenor Sax-horn, the horns. The baritone Sax-horn, the alto Trombone and the alto Ophicleide. The bass Sax-horn, the bass Trombone and the bass Ophicleïde. The Bombardon, the contra-bass Trombone and the contra-bass Ophicleïde".

"La famille des Sax-horn remplace les Instrumens suivans: le Sax-horn Soprano, le Bugle en Mib. Le Sax-horn Contralto, le Bugle en Sib. Le Sax-horn Tenore, les Cors. Le Sax-horn Baryton, le Trombonne et l'Ophicleïde alto. Le Sax-horn Basse, le Trombonne et l'Ophicleïde Basse. Le Bombardon, le Trombonne et l'Ophicleïde Contre-Basse". ${ }^{3}$

1850-1854 After a three-year pause, nine new methods were published. It should be noted that after the political changes in France in the wake of the I848 Revolution and a new ministerial decree of 2I March I848, the "sax" prefix was removed from instruments designated for military bands. Now they were called "clairons chromatiques". ${ }^{4}$ Some of the subsequent publications carry the new official name of the instrument. This publication period ended with the I854 decree that re-established the "système Adolphe Sax" as the standard instrumentation for military bands and named the instruments saxhorns again. But there were two changes in the names of the instruments of the saxhorn family. From now on, the former sopranino in $\mathrm{E}$ b was called soprano, while the soprano in $\mathrm{B}$ b was called contralto. ${ }^{5}$

1861-1865 A third period of publications of saxhorn tutors started in I86I. It seems that the authors of the new methods were the first generation to have grown up with the instrument, and were now taking over the teaching positions of their predecessors. Most tutors use the name saxhorn.

Victor Cornette: Méthode complète de sax-horn soprano, contralto, ténor, barpton basse et contrebasse (ou bombardon), Paris: Richault [I846], p. 3.

4 Malou Haine: Adolphe Sax, sa vie son oeuvre, ses instruments de musique, Brussels I980, p. I07.

5 Ibid., p. II3. 
The tutors of I858 and I859 are special cases. The number of the printing plate of the tutor by Hartmann suggests that it could have been published about ten years earlier, and would thus belong to the first publication period. ${ }^{6}$ The Dupart tutor was one of a series of small booklets for all instruments that were to be used in school bands.

Conclusion Within the first 20 years of the instrument's invention, a total of 35 saxhorn tutors by 25 authors was published. They came onto the market in three periods that were clearly related to the decrees of I845, I848 and I854 respectively on the composition of military bands, though this period division could also be a result of generational change among saxhorn teachers.

Saxhorn tutors versus cornet tutors Taking our cue from the brass tutors and teaching methods in use today, we might think that most tutors for the saxhorn were actually cornet tutors that could be used for the saxhorn as well. Yet a closer look at these titles reveals that only eight of them were tutors intended for the cornet or saxhorn, whereas 27 claim explicitly to be specialist tutors for saxhorns only.

Furthermore, we can subdivide the tutors for saxhorn only into three categories:

- Tutors for all saxhorns without further specification (6)

- Tutors explicitly written for one specific type of saxhorn (II)

- Tutor collections with an individual book for each type of saxhorn, but similar in content (Io)

Half of the specialist tutors were intended for saxhorn basse. The reason for this could be the notation in transposed bass clef and the $4^{\text {th }}$ valve of the instrument, which gives the saxhorn basse an extended lower range. In methods published for more than one instrument with an individual volume for each, there is often a bass clef and a treble clef version for saxhorn basse and contrebasse, so we can surmise that both keys were used on a regular basis.

The contents of early saxhorn tutors There is a high variety in the contents of the abovementioned 35 early saxhorn tutors. Nevertheless, they can be ordered into 3 main categories:

- "Grandes" methods (also "Méthodes complètes"): "Large methods" intended for the advanced student, well-structured with a lot of rather demanding studies for future professionals. Typical examples of this type of tutor are the Grande méthode complète de Cornet à pistons (1864) by Arban and the Méthode complète (I844) by Forestier. 

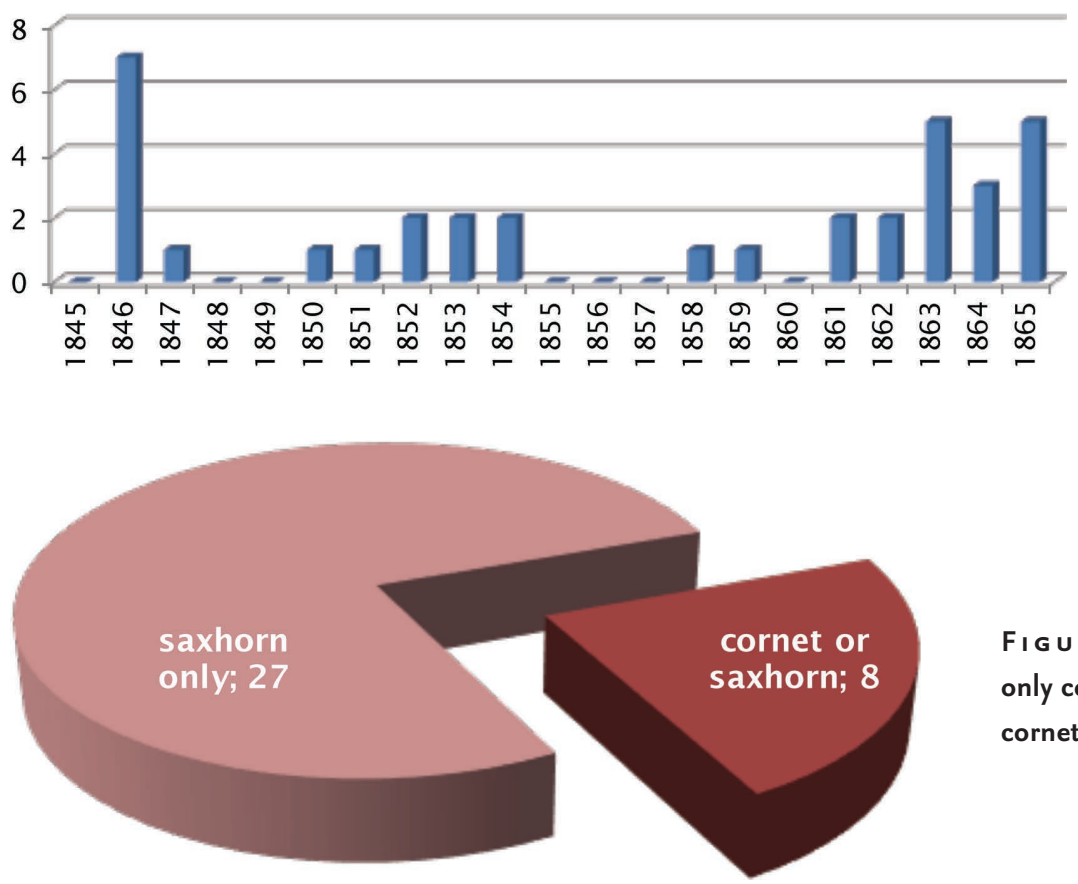

Figure 2 Number of saxhorn tutors by year of publication
FIgURE 3 Tutors for saxhorn only compared to tutors for cornet or saxhorn

Methods for one specific type of saxhorn; 11

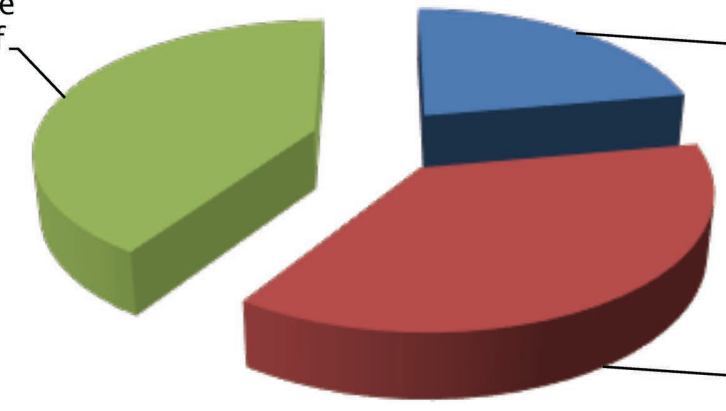

Methods for all saxhorns; 6

FIguRE 4 Specialist tutors within the saxhorn family

Collections with individual books for each type; 10

Sax, Ad olphe (1846)

Fessy, Alexandre (1846)

Forestier, Joseph (1846)

Caussinus, Victor (1846)

Cornette, Victor (1846)

$0 \%$

\begin{tabular}{|c|c|c|c|c|c|}
\hline \multirow[t]{2}{*}{$0 \%$} & $20 \%$ & $30 \%$ & $50 \%$ & $80 \%$ & $90 \% \quad 100 \%$ \\
\hline & $\begin{array}{c}\text { Cornette, Victor } \\
(1846)\end{array}$ & $\begin{array}{c}\text { Caussinus, Victor } \\
\text { (1846) }\end{array}$ & $\begin{array}{c}\text { Forestier, Joseph } \\
\text { (1846) }\end{array}$ & $\begin{array}{c}\text { Fessy, Alexandre } \\
(1846)\end{array}$ & Sax, Ad olphe (1846) \\
\hline Théorie & $9 \%$ & $37 \%$ & $11 \%$ & $17 \%$ & $11 \%$ \\
\hline Études & $3 \%$ & $62 \%$ & $13 \%$ & $67 \%$ & $64 \%$ \\
\hline Leçons & $8 \%$ & $0 \%$ & $76 \%$ & $6 \%$ & $0 \%$ \\
\hline Morceaux (Solos) & $0 \%$ & $0 \%$ & $0 \%$ & $11 \%$ & $0 \%$ \\
\hline Morceaux (Duets) & $22 \%$ & $1 \%$ & $0 \%$ & $0 \%$ & $0 \%$ \\
\hline Solos, Du os de concert & $59 \%$ & $0 \%$ & $0 \%$ & $0 \%$ & $17 \%$ \\
\hline Trios etc. & $0 \%$ & $0 \%$ & $0 \%$ & $0 \%$ & $9 \%$ \\
\hline
\end{tabular}

F I GURE 5 Contents of five early "Méthodes complètes". Cornette's tutor consists mainly of duets and solos, Forestier's whole tutor is founded on "leçons", while Caussinus focuses on etudes. 
- "Petites" methods: These "little methods" were intended for beginners and intermediate students. Often, they contain not much more than scales, long notes and a few duets or transcriptions of short airs. The contents are quite exchangeable. Often it seems as if the same "Petite méthode" could have been sold to players of just about any instrument, with only the title page changed each time.

- Collections: Some authors published collections of tutors, with a separate book for different types of saxhorn. They are often identical, with only the title page having been changed. While some of them also bear the title "Petite méthode", they tend to be rather more sophisticated than the usual method of that type.

A typical example of the last category can be identified by looking at the plate numbers of the 1846 tutor by Cornette. While the first page with the name of the instrument in the title carries the number "S. I28I", page 2 refers to "S. I28I-I282. I283. I285. I284. I286". It appears that page 2 was identical for all the books in this collection. The order of the plate numbers shown on the page is quite peculiar. It could be that this is due to the order in which the separate volumes were printed.

The editor and composer Carnaud (Jeune) not only published a large Méthode complète et raisonnée 7 but also a number of small, 30-page tutors for flute, cornet, trumpet, side drum and violin with more or less similar content. ${ }^{8}$

In the "Grandes" methods or "Méthodes complètes", we typically find the following contents:

- Théorie: A theoretical part that describes the instrument, introduces musical notation and note values, reports on mouthpiece issues, and offers a fingering chart and scales.

- Études: Short studies of considerable difficulty, intended to practise a particular musical skill.

- Leçons: A couple of small studies assembled together to form a single lesson, to be worked on during one or more sessions with a teacher.

7 [Félix] Carnaud (Jeune): Méthode complète et raisonnée pour les sax-horns contrebasse et barpton à 3 à 4 et à 5 cplindres et pour le trombone à 3 pistons, Paris 1852 .

8 Some of Carnaud's "petites" methods containing between 24 and 36 pages are: [Félix] Carnod (Jeune): Nouvelle Méthode pour flageolet, écrite à l'unisson de la petite flûte pour jouer sans transposition les parties de flûte des orchestre de danse, Paris I846; id.: Méthode pour la musette sans clefs, à 4, 5, 6 et 7 clefs, Paris I857; id.: Méthode de sax-horns, Paris I863; id.: Méthode pour le flageolet à I à 2, à 3, à 4 ou à 5 clefs, Paris I865; id.: Méthode pour la flûte à I, 4, 5 ou 6 clefs, Paris I865; id.: Méthode pour la trompette à pistons, Paris I869; id.: Méthode pour la trompette d'harmonie et de cavalerie, Paris I869; id.: Méthode d'un nouveau spstème pour l'harmonies et pour le Métallophone, Paris I869; id.: Ecole du tambour ou méthode pour apprendre à battre la caisse, Paris I870; id.: Méthode pour le clairon, Paris I870; id.: Méthode pour le violon analptique et progressive, Paris: A. Pruvost \& C.ie. [n.d.]. 
- Morceaux (solos): Small solo pieces, often with piano accompaniment.

- Morceaux (duets): Small duets to be played by students or by a student and his or her teacher.

- Solos/Duos de concert: Longer solo or duet pieces to be played at a concert. Often, these are transcriptions of operatic arias.

- Chamber music: Pieces to be played by more than two people.

If we compare five "Grandes" methods, we can see that they follow quite different pedagogical concepts.

Teaching concepts Teaching concepts used in early saxhorn tutors are quite individual and seem to reflect the teaching methods and preferences of their respective authors.

The contents of Cornette's tutor could be summarised as follows:

- I page with a picture of a saxhorn

- 6 pages of theory

- 4 pages of scales and exercises for a single player

- 8 I pages of duets

The contents thus reveal a pedagogical concept that focuses on a teacher playing with his or her student, and provides $90 \%$ of the material needed for this. As an example of this practice, we can consider the first of the duets in this tutor. The student plays the half notes on the first system, while the teacher plays the more complex bass line. ${ }^{9}$

Adolphe Sax bases his tutor on studies ordered by scales. It is not clear whether all the studies belonging to a scale are considered to be lessons, and if they are intended to be worked through in the order in which they appear in the book. The first scales are $\mathrm{C}$ major and a minor, and all the exercises are related to these tonics. While the C-major exercises are a little more elaborate, the a-minor exercises seem to serve as a model for the other scales.

- Exercise r: the a-minor scale and its tonic chord (over two octaves!)

- Exercise 2: intervals

- Exercise 3: arpeggios of the main chords of a minor

- I lyric piece (andante) focusing on the a-minor scale

- I piece at moderate tempo (moderato) focusing on the a-minor scale

- I lyric piece (andante) focusing on arpeggios

- I swifter piece (allegro) focusing on arpeggios

- I technical piece (moderato) focusing on arpeggios 


\section{- $\rightarrow$ 4.}

\section{VINGT LEGONS ÉLÉMENTAIRES ET PROGRESSIUES,}

Pnur habiluer à la lecture de la Musique et tenant_lieu de Leçons de Sólfège.. $\$$
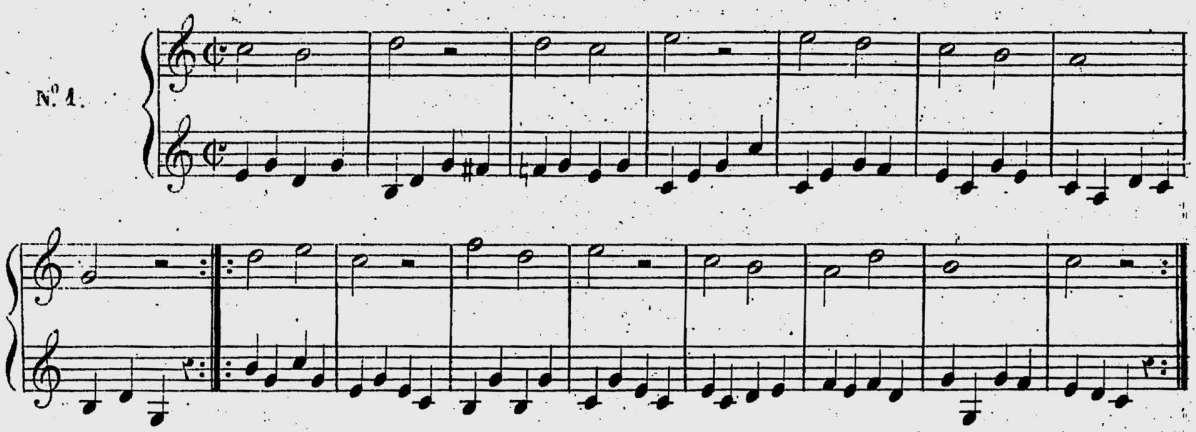

N.'2.
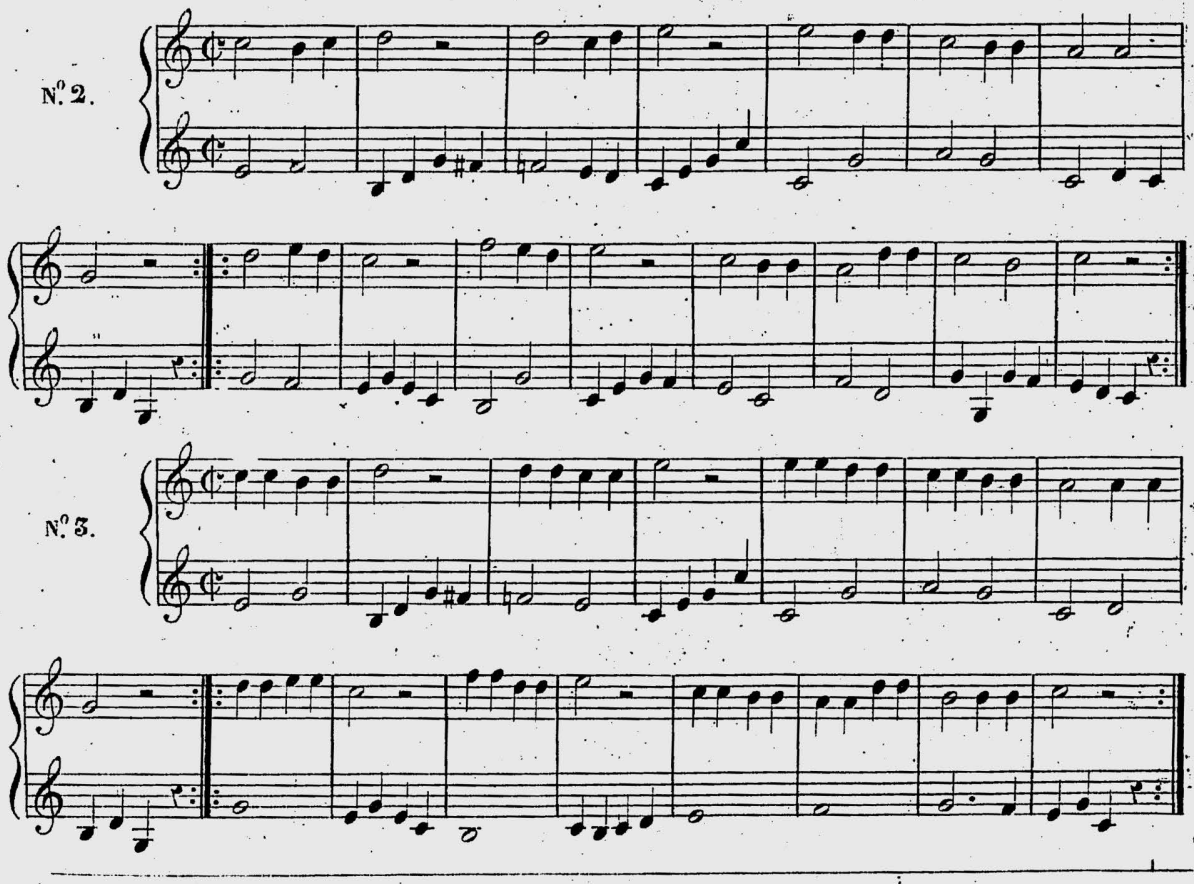

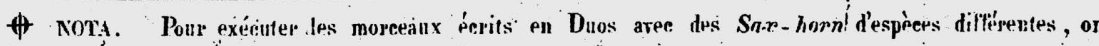
suivra les indieations survantes: :

Qund le Soprinno, qui est en MI b, T T Ound le Contralto, qui est SI b, joue . joure en UT'; It Contraltiri, qui est en . Contralto el Tenore. $\{$ en LT, le Tenore, qui est en MI b,juera

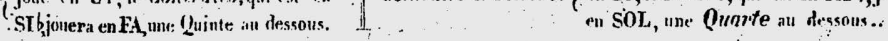

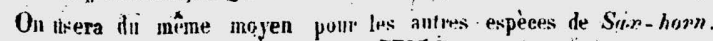
Tris.5 is

FIGURE 6 In his Méthode complète, Cornette focuses on duets played by the teacher and the student. 
- I lyric piece (andantino) combining scales and arpeggios

- I swifter piece (allegro moderato) combining scales and arpeggios

This is followed by the next scale topic - G major - which has more or less the same structure. Not surprisingly, this tutor offers the most detailed pictures of the instrument. $^{\text {IO }}$

After publishing a cornet tutor in $\mathrm{I} 844,{ }^{\mathrm{II}}$ Joseph Forestier then published an entirely new saxhorn tutor in $1846 .{ }^{\mathrm{I2}} \mathrm{He}$ focuses on lessons for specific musical problems. His saxhorn tutor includes 20 progressive lessons followed by I4 caprices. The topics of the first few lessons are:

- Lesson r: "Pour servir à la formation du son" (Long notes)

- Lesson 2: "Ut majeur" (C major)

- Lesson 3: "Avec addition d'une note aigüe" (an additional high note)

- Lesson 4: "La mineur" (a minor)

- Lesson 5: "Avec addition d'une note aigüe et d'une note grave" (additional high and low notes)

- Lesson 6: "Sol majeur" (G major)

$-\quad \ldots$

- Lesson I5: "Exercices pour la langue" (tonguing exercises)

As these lessons seem to be presented in a progressive order of difficulty, Forestier carefully tries to avoid excessive demands on the student's range. Not all tutors master this problem in such a manner.

Range Every brass teacher knows that Arban's famous method cannot be used for beginners. One of its main problems is the range of most of its etudes. If we compare the range featured in the first four lessons of early saxhorn tutors, we see that this wide range was in fact usual at the time. The only tutor that could actually have been used for beginners was the Petite méthode by Blancheteau, but even this tutor covers a full octave in the first two exercises (see Figure 8). ${ }^{\mathrm{I3}}$

Conclusions Over the course of the first 20 years after the saxhorn's appearance, a large variety of instrumental tutors were published for it. This shows that this new instrumen-

10 Sax: Méthode complète, pp.3f.

11 Joseph Forestier: Méthode complète théorique et pratique pour le cornet à pistons, Paris I844.

12 Joseph Forestier: Méthode complète pour les sax-horns ou bugles mib aigu (soprano), en sib (Contralto) en mib grave (alto ou ténor) ou sax-tromba ou trombonne-alto à 3 cplindres, Paris 1846 , see http://gallica.bnfffr (27 June 2018).

13 A. Blancheteau: Petite méthode de sax-horhs [sic], 9 vols., Paris I863. 


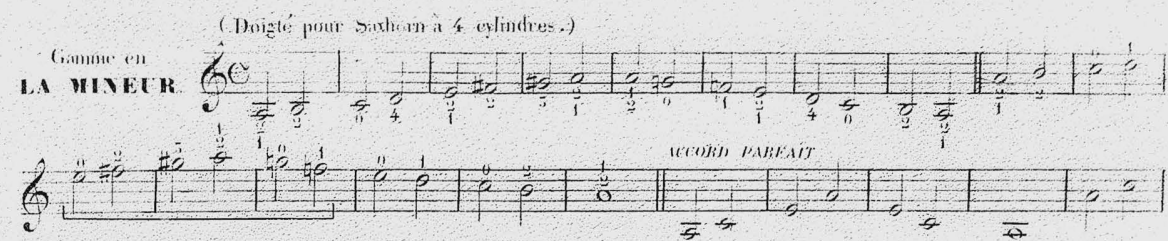

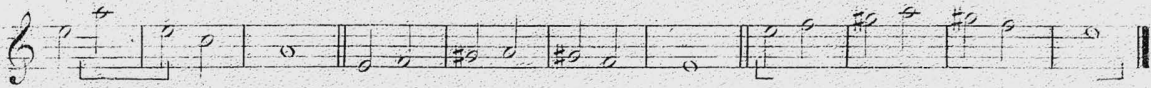

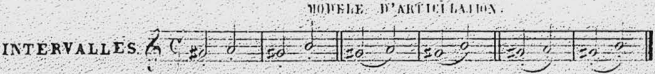

(Doiglé ordinaire.)

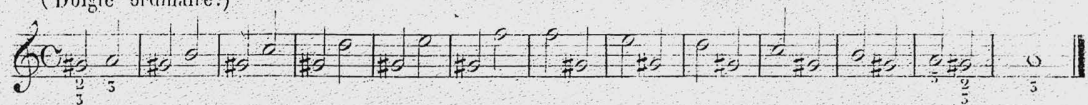

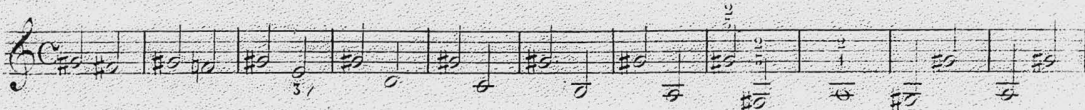

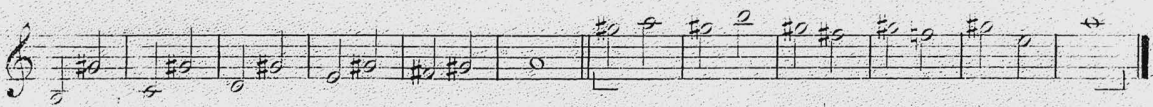

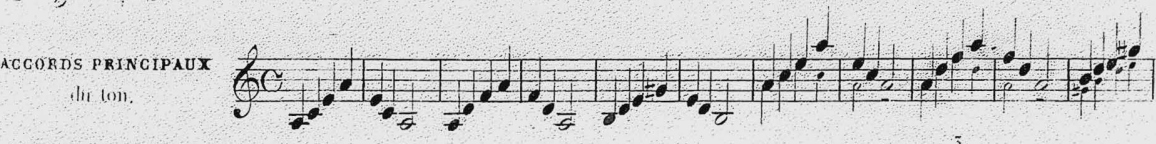

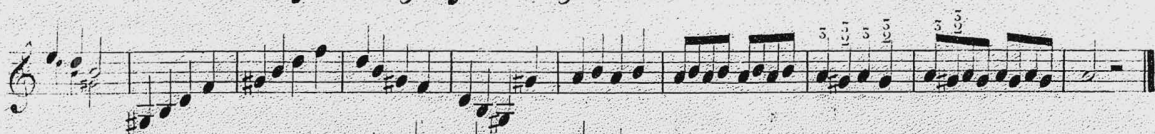

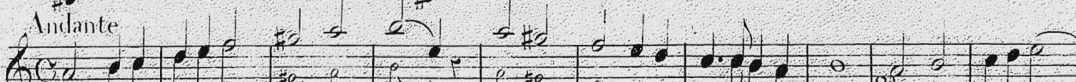

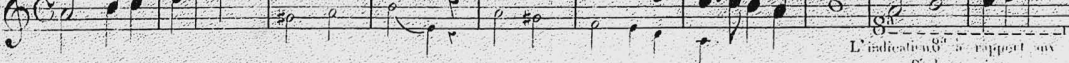
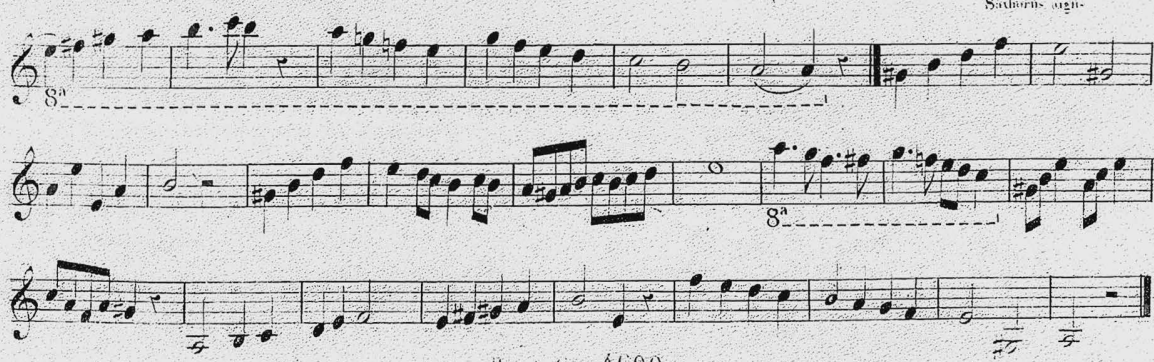

FIgURE 7 The a-minor scale in the saxhorn tutor by Adolphe Sax, p. 13 


\begin{tabular}{|c|c|c|c|}
\hline Tutor & Range & Tutor & Range \\
\hline $\begin{array}{l}\text { Cornette, Victor (I846) } \\
\text { Méthode complète }\end{array}$ & $g_{4}-f 5$ & Fessy, Alexandre (I847) & $c_{4}-f 5$ \\
\hline $\begin{array}{l}\text { Cornette, Victor (I846) } \\
\text { (Collection de méthodes) }\end{array}$ & $c_{4}-f_{5}$ & Schiltz (1852) & $c_{4-\xi}$ \\
\hline Fessy, Alexandre (I846) & $c_{4}-e_{5}$ & Hartmann (1858) & $c_{4}-95$ \\
\hline Forestier, Joseph (I846) & $c_{4}-d_{5}$ & Blancheteau (I863) & $c 4-c 5$ \\
\hline Sax, Adolphe (I846) & $a_{3}-c 6$ & Saverio (I865) & $h_{3}-g 5$ \\
\hline
\end{tabular}

FIGURE 8 The demands on the range made in early saxhorn tutors in the course of the first four lessons

tal family by Adolphe Sax must have had an immediate, immense impact - a supposition that would seem to be supported by Berlioz's articles in the Journal des débats about the contest of $1845 .{ }^{\mathrm{I} 4}$

A further analysis of publication dates shows that there have been three principal periods of publication for tutors that correlate with ministerial decrees on the composition of military bands. Whereas some tutors seem to originate in collections for several instruments, there is a significant number of tutors that offer a highly specialised approach to saxhorns.

There are three categories of saxhorn tutors: "Grandes" methods, "Petites" methods, and collections of "Méthodes" for several instruments. All of these contain a theoretical section, usually followed by studies, scales, duets and often transcriptions of opera arias to be played as solos.

Comparing five different "Grandes" methods demonstrates a variety of didactical concepts that can be categorised along three main ideas: Some have a focus on lessons to be used successively, being organised in ascending difficulty; others are organised according to specific musical topics or problems (often scales), while others focus on the teacher playing with the student, and offer many duets and solos. It is clear that all of these "Grandes" methods are intended for advanced students who are preparing for a professional career in military bands or orchestras. Despite offering some very basic theory and exercises, the high demands made on the range of the player, even in the initial exercises, mean it is not surprising that hardly any tutors seem appropriate for use by a beginner student.

14 Hector Berlioz: De la réorganisation des musiques militaires, in: Journal des débats, I April I845, pp. I-3, and Berlioz: Concours des musiques militaires au Champ-de-Mars, in:Journal des débats, 29 April I845, p. [2]. 


\section{Inhalt}

Vorwort 7

Adrian von Steiger "Agilité, homogénéité et beauté". The Saxhorn in the Context of the Opéra and Military Music 9

Eugenia Mitroulia/Arnold Myers The Saxhorn Families I8

Malou Haine Une nouvelle source d'archives pour identifier les marques de fabrique de facteurs d'instruments de musique (I860 à I9I9)

Stewart Carter Kastner, the Distin Family, and the Emergence of the "New" Brasswind Instruments by Adolphe Sax 68

Sabine K. Klaus Wieprecht versus Sax. German Roots of Adolphe Sax's Brasswind Designs 97

Ignace De Keyser The Construction of the Genius in

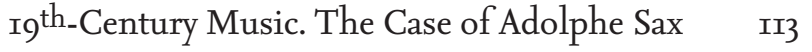

Cyrille Grenot Deux faillites d'Adolphe Sax, I873 et I877. Présentation et documents $\quad$ I46

Reimar Walthert The First Twenty Years of Saxhorn Tutors $\quad 155$

Bruno Kampmann French Makers' Improvements on Brass Instruments in the mid-I th $^{\text {th }}$ Century, Compared with Those by Adolphe Sax $\quad$ I68

Jeroen Billiet Adolphe Sax's Ultimate Masterpiece. The History, Design and Use of the Cor Sax à six pistons indépendants $\quad$ I76

Daniel Allenbach „Une réforme tellement logique« oder »à classer au rang des utopies«? Henri Chaussiers »instruments en Ut« $\quad$ I88

Gregor Widholm Das Wiener Horn - ein Instrument des I9. Jahrhunderts als erste Wahl in Orchestern des 2I. Jahrhunderts 223

Martin Skamletz »... und gar nichts, wodurch sich der eigene schöpferische Geist des Komponisten beurkundete«. Cherubini, Hummel, Konzerte, Opern, Quodlibetes und Trompeten in Wien zu Beginn des I9. Jahrhunderts.

Teil 3 und Schluss: Anton Weidinger und sein Instrument 245

Rainer Egger/Martin Mürner $\quad$ Restaurierungsergebnisse messbar machen $\quad 262$ Namen-, Werk- und Ortsregister 272

Die Autorinnen und Autoren der Beiträge $\quad 283$ 


\section{DAS SAXHORN}

Adolphe Sax' Blechblasinstrumente im Kontext ihrer

Zeit. Romantic Brass Symposium 3 - Herausgegeben von Adrian von Steiger, Daniel Allenbach und Martin Skamletz 


\section{MUSIKFORSCHUNG DER Hochschule der KÜnste Bern Herausgegeben von Martin Skamletz und Thomas Gartmann}

Band 13 
2 Dieses Buch ist in gedruckter Form im April 2020 in erster Auflage in der Edition Argus in Schliengen/Markgräflerland erschienen. Gestaltet und gesetzt wurde es im Verlag aus der Seria und der SeriaSans, die von Martin Majoor im Jahre 2000 gezeichnet wurden. Gedruckt wurde es auf Eos, einem holzfreien, säurefreien, chlorfreien und alterungsbeständigen Werkdruckpapier der Papierfabrik Salzer im niederösterreichischen Sankt Pölten. Das Vorsatzpapier Caribic cherry wurde von Igepa in Hambug geliefert. Rives Tradition, ein Recyclingpapier mit leichter Filznarbung, das für den Bezug des Umschlags verwendet wurde, stellt die Papierfabrik Arjo Wiggins in Issy-les-Moulineaux bei Paris her. Das Kapitalband mit rot-schwarzer Raupe lieferte die Firma Dr. Günther Kast aus Sonthofen im Oberallgäu, die auf technische Gewebe und Spezialfasererzeugnisse spezialisiert ist. Gedruckt und gebunden wurde das Buch von der Firma Bookstation im bayerischen Anzing. Im Internet finden Sie Informationen über das gesamte Verlagsprogramm unter www.editionargus.de, zum Institut Interpretation der Hochschule der Künste Bern unter www.hkb.bfh.ch/interpretation und www.hkb-interpretation.ch. Die Deutsche Nationalbibliothek verzeichnet diese Publikation in der Deutschen Nationalbibliografie; detaillierte bibliografische Daten sind im Internet über www.dnb.de abrufbar. (C) der zeitgleich erschienenen digitalen Version: die Autorinnen und Autoren, 2020. Dieses Werk ist lizenziert unter einer Creative Commons Namensnennung-Nicht kommerziell 4.0 International Lizenz (CC BY-NC 4.o). DOI: https://doi.org/I0.26045/kp64-6I77 ISBN 978-3-93I264-93-2 